\title{
Methods of evaluation of microvascular structure: state of the art
}

\section{Matteo Nardin ${ }^{1 *}$, Maria Antonietta Coschignano ${ }^{1 *}$, Claudia Rossini ${ }^{1}$, Carolina De Ciuceis ${ }^{1}$, Stefano Caletti ${ }^{1}$, Marco Rizzoni ${ }^{2}$, Franco Docchio ${ }^{3}$, Enzo Porteri ${ }^{1}$, Damiano Rizzoni ${ }^{4}$}

\author{
* The first two authors have equally contributed to the manuscript \\ ${ }^{1}$ Clinica Medica, Department of Clinical and Experimental Sciences, University of Brescia, Italy \\ 2 Department of Information Engineering, University of Brescia, Brescia, Italy \\ ${ }^{3}$ Department of Mechanical and Industrial Engineering, University of Brescia, Italy \\ ${ }^{4}$ Istituto Clinico Città di Brescia, Division of Medicine, Brescia, Italy
}

\begin{abstract}
Cardiovascular diseases represent the leading cause of death in Western Countries. Among them, a key role is played by arterial hypertension, which causes macro- and microvascular alterations. Specifically, hypertension is associated with structural alterations in the microvessels, such as an increased ratio of the tunica media thickness to internal lumen ( $\mathrm{M} / \mathrm{L}$ ratio) in small resistance arteries and a reduction of capillary density. In order to evaluate the small resistance artery structure, the direct measurements of $M / L$ ratio through wire or pressure micromyography has been considered the gold-standard method. Despite the availability of convincing evidence about the prognostic relevance of the $\mathrm{M} / \mathrm{L}$ ratio, the invasiveness of these methods has limited its implementation in the daily clinical practice. Therefore, non-invasive techniques have been developed to evaluate microvascular morphology, particularly in the retina, since it is perhaps the most accessible microvasculature. Scanner laser Doppler flowmetry (SLDF) and adaptive optics (AO) represent the most promising approaches for the evaluation of morphological characteristics of retinal arterioles, in particular for the measurement of their wall-to-lumen ratio (W/L ratio). The possibility to evaluate microvascular morphology by non-invasive techniques represents a major clinical advancement, with possibly favorable implications in research and in stratification of cardiovascular risk. In this review we will address the different methods to investigate the microcirculation as well as their clinical usefulness.

Keywords: microcirculation $\bullet$ small resistance artery $\bullet$ micromyography $\bullet$ adaptive optics $\bullet$ scanner laserDoppler flowmetry
\end{abstract}

\section{Citation}

Nardin M, Coschignano MA, Rossini C, De Ciuceis C, Caletti S, Rizzoni M, et al. Methods of evaluation of microvascular structure: state of the art. Eur J Transl Clin Med 2018;1(1):9-19.

DOI: $10.31373 /$ ejtcm/95161

\section{Introduction}

Arterial hypertension is one of the major causes of cardiovascular diseases worldwide; in patients with hypertension the risk of coronary heart disease, congestive heart failure, ischemic and hemorrhagic stroke, renal failure and peripheral arterial disease is more than doubled [1]. There is a general agreement on the

Corresponding author:

Damiano Rizzoni, Istituto Clinico Città di Brescia, Division of Medicine, Brescia, Italy, c/o 2a Medicina, Spedali Civili, 25100 Brescia, Italy

e-mail: damiano.rizzoni@unibs.it

Available online: ejtcm.gumed.edu.pl

Copyright $\circledast$ Medical University of Gdańsk

This is Open Access article distributed under the terms of the Creative Commons Attribution-ShareAlike 4.0 International (CC BY-SA 4.0); license available at: https:// creativecommons.org/licenses/by-sa/4.0/. 
fact that essential hypertension is associated with the presence of structural alterations in the microcirculation [2-6], that represent that part of the vascular tree in which the major part of energy dissipates in order to overcome resistance.

The human vasculature is composed of large vessels (diameter $>300 \mu \mathrm{m}$ ) and of small vessels (diameter $<300 \mu \mathrm{m})$. The microcirculation includes the small arteries (diameter ranging from 100 and $300 \mu \mathrm{m}$ ), the arterioles (diameter $<100 \mu \mathrm{m}$ ) and the capillary network (diameter around $7 \mathrm{~mm}$ ). Small arteries probably contribute for about $30-50 \%$ of precapillary blood pressure drop, although an additional 30\% drop occurs at the arteriolar level [6-7]. An increase in the vascular wall thickness, together with a reduction in the internal diameter, may play a major role in the increased peripheral resistance observed in hypertension.

\section{Small resistance artery remodeling}

Peripheral resistance is determined by two independent components: active properties (mainly contraction) and structural properties (lumen diameter, wall thickness, number and re-arrangement of smooth muscle cells) of small arteries. The increase in resistance to flow that accompanies hypertension may be due partly to an increase in the vasoconstrictor tone, caused by activation of neurohumoral functional mechanisms, and partly to the increase in the wall thickness (mainly tunica media thickness) of the small arteries in relation to the lumen ( $\mathrm{M} / \mathrm{L}$ ratio) [4]. The increase in the $\mathrm{M} / \mathrm{L}$ ratio of the small resistance arteries per se may lead to greater vasoconstriction for any degree of shortening of smooth muscle cells, thus enhancing the effect of any vasoconstrictor stimulus. This phenomenon represents a critical element in the maintenance and progressive aggravation of hypertension [4].

The increase in $M / L$ ratio of human subcutaneous small resistance arteries can be caused by two different types of remodeling. The first one is the hypertrophic remodeling: the increase in the $M / L$ ratio and in the cross-sectional area is due to hypertrophy and/or hyperplasia of the vascular smooth muscle cells. An increased $\mathrm{M} / \mathrm{L}$ ratio may also be due to eutrophic remodeling, that consist in a rearrangement of the same amount of wall material around a smaller lumen without an increase in the cross-sectional area. In patients with essential hypertension, an eutrophic remodeling was generally observed; on the contrary in patients with secondary forms of hypertension a hypertrophic vascular remodeling was detected [8].

A significant correlation between coronary flow reserve and subcutaneous small resistance artery remodeling has been detected in hypertensive patients [9], suggesting that structural alterations in small resistance arteries may be present at the same time and with similar characteristics in different vascular beds. An increased $M / L$ ratio of subcutaneous small resistance arteries is also present in diabetic and in obese patients [10-12]. It seems that the simultaneous presence of several cardiovascular risk factors may have a synergistic and deleterious effect on the microcirculation.

A relevant prognostic role of structural alterations in the microcirculation has been demonstrated independently from the blood pressure values [13] and also during antihypertensive treatment [14]. In fact, an increased $\mathrm{M} / \mathrm{L}$ ratio of subcutaneous small resistance arteries is associated with a reduced event-free survival. The $M / L$ ratio of small arteries and the pulse pressure are both major predictors of cardio-cerebrovascular events. Therefore, microvascular structure evaluation represents an important element also in terms of cardiovascular risk stratification [15-16].

\section{Microvascular rarefaction}

The vascular resistance of a tissue is determined also by the absolute number of perfused microvessels. In fact, another mechanism involved in the increase of vascular resistance is the reduction of microvascular density (rarefaction), which mainly affects the smaller vessels (less than $100 \mu \mathrm{m}$ ) such as arterioles and capillaries [17].

Rarefaction may be functional, when the microvessels are temporarily non-perfused or recruited, or anatomical, when the vessels are permanently absent. There is little information available about the mechanisms involved in the control of capillary density in the different vascular districts. Numerous studies have shown the presence of microvascular rarefaction in animal models [18]. In humans, several studies demonstrated a reduction of the number of capillaries in the skin of the dorsum of the finger of patients with essential hypertension [19-20]. It is not currently known whether capillary rarefaction may possess a prognostic significance per se, but there is evidence suggesting a correlation between capillary rarefaction and the $\mathrm{M} / \mathrm{L}$ ratio of subcutaneous small arteries [21].

\section{Methods for the evaluation of micro- vascular structure}

The methods for the evaluation of microvascular structural alterations available in humans are relatively few. Some of them are described in Table 1. One of the first methods proposed many years ago has been the evaluation of minimum vascular resistance in the forearm by plethysmography. Minimum vascular resistance, calculated from maximum post-ischemic flow and mean blood pressure was demonstrated to be correlated with 
the $\mathrm{M} / \mathrm{L}$ ratio of subcutaneous small resistance arteries [22].

A critical element inherent in this approach is the need to obtain true maximum vasodilatation, which is achieved via ischemia, muscular effort and heat. In condition of maximum post ischemic blood flow it is possible to calculate the minimum vascular resistance. Forearm minimum vascular resistance represents, therefore, an indirect index of microvascular structural alterations that may be assessed non-invasively with minimum discomfort.
In more details, the plethysmographic technique consists in a complete occlusion of the brachial artery of the dominant arm through the inflation of a sphygmomanometer up to $300 \mathrm{mmHg}$ for about 13 minutes and a subsequent dynamic exercise (i.e 20-30 hand grips against a fixed resistance). The arterial occlusion is rapidly removed while venous occlusion is maintained (around $60 \mathrm{mmHg}$ of pressure) [23]. If venous backward flow is absent, the increased volume of the forearm evaluated through a plethysmographic sensor around the forearm provides an estimation of forearm arterial

Table 1. Main methods and measurements to assess microcirculation in humans

\begin{tabular}{|c|c|c|c|c|c|}
\hline & Advantages & Disadvantages & Reproducibility & Clinical impact & $\begin{array}{c}\text { Comparison between } \\
\text { methods }\end{array}$ \\
\hline $\begin{array}{l}\text { Micromy- } \\
\text { ography }\end{array}$ & $\begin{array}{l}\text { Gold standard for } \\
\text { the evaluation of } \\
\text { vascular morphology } \\
\text { and function. high } \\
\text { sensitivity, specificity } \\
\text { and accuracy }\end{array}$ & $\begin{array}{l}\text { Locally invasive; } \\
\text { well trained } \\
\text { personnel; bias } \\
\text { relate to mechanical } \\
\text { damage of the } \\
\text { vessel. }\end{array}$ & $\begin{array}{l}\text { Highly reproducible: } \\
\text { pressure } \\
\text { micromyography } \\
\text { better for functional } \\
\text { values, and wire } \\
\text { micromyography for } \\
\text { morphological data }\end{array}$ & $\begin{array}{l}\text { Prognostic impact } \\
\text { on cardiovascular } \\
\text { outcomes (for M/L } \\
\text { ratio) [13] }\end{array}$ & \\
\hline $\begin{array}{l}\text { Capillary } \\
\text { density }\end{array}$ & $\begin{array}{l}\text { Not expensive, non } \\
\text { invasive }\end{array}$ & $\begin{array}{l}\text { Operator } \\
\text { dependent.. } \\
\text { Influence of skin } \\
\text { transparency, } \\
\text { previous hand } \\
\text { beauty treatments, } \\
\text { or manicure. }\end{array}$ & $\begin{array}{l}\text { Observer errors } \\
\text { and biological } \\
\text { variation can affect } \\
\text { reproducibility [87] }\end{array}$ & $\begin{array}{l}\text { Relationship } \\
\text { between } \\
\text { hypertension } \\
\text { and capillary } \\
\text { rarefaction [19, } \\
88 \text { ] }\end{array}$ & $\begin{array}{l}\text { Relationship between } \\
\text { M/L ratio and } \\
\text { microvessel density } \\
\text { in dermal tissue in } \\
\text { normotensive and } \\
\text { essential hypertensive } \\
\text { patients [21] }\end{array}$ \\
\hline $\begin{array}{l}\text { Plethysmo- } \\
\text { graphy }\end{array}$ & $\begin{array}{l}\text { Not expensive; } \\
\text { minimal discomfort } \\
\text { for the patients; } \\
\text { possibility of } \\
\text { pharmacological } \\
\text { studies }\end{array}$ & $\begin{array}{l}\text { Challenging; } \\
\text { need for } \\
\text { standardization, } \\
\text { need for operator } \\
\text { training. }\end{array}$ & & & $\begin{array}{l}\text { Relationship } \\
\text { demonstrated between } \\
\text { minimal vascular } \\
\text { resistance and M/L ratio } \\
\text { of subcutaneous small } \\
\text { arteries [22] }\end{array}$ \\
\hline $\begin{array}{l}\text { Fun- } \\
\text { duscamera } \\
\text { assessing } \\
\text { AVR }\end{array}$ & $\begin{array}{l}\text { Dimensionless, } \\
\text { relatively easy to } \\
\text { perform. }\end{array}$ & $\begin{array}{l}\text { Nonspecific. } \\
\text { Changes in } \\
\text { arteriovenous } \\
\text { may reflect changes } \\
\text { in arteriolar or } \\
\text { venular } \\
\text { diameter or both }\end{array}$ & $\begin{array}{l}\text { Reduced } \\
\text { reproducibility: } \\
\text { dependence on } \\
\text { selected vessels } \\
\text { [89] }\end{array}$ & $\begin{array}{l}\text { A correlation } \\
\text { between AVR } \\
\text { and incidence of } \\
\text { cardiovascular } \\
\text { events was } \\
\text { detected only in } \\
\text { woman [13] }\end{array}$ & $\begin{array}{l}\text { Lack of association } \\
\text { between AVR and W/L } \\
\text { ratio of retinal arterioles } \\
\text { assessed by SLDF [74] }\end{array}$ \\
\hline $\begin{array}{l}\text { Fractal } \\
\text { dimension }\end{array}$ & $\begin{array}{l}\text { Non invasive, low } \\
\text { cost }\end{array}$ & $\begin{array}{l}\text { Geometry of the } \\
\text { eye could affect the } \\
\text { determination } \\
\text { No consensus on } \\
\text { calculation of fractal } \\
\text { geometry [90] }\end{array}$ & $\begin{array}{l}\text { Magnification } \\
\text { differences in retinal } \\
\text { images can influence } \\
\text { the measurements } \\
\text { [91] }\end{array}$ & $\begin{array}{l}\text { Independent } \\
\text { predictor of } 14- \\
\text { year coronary } \\
\text { heart disease } \\
\text { mortality [53] } \\
\text { Associated with } \\
\text { lacunar stroke[92] } \\
\text { and blood pressure } \\
\text { [55] }\end{array}$ & \\
\hline SLDF & $\begin{array}{l}\text { Non invasive; } \\
\text { relatively easy }\end{array}$ & $\begin{array}{l}\text { Not extensively } \\
\text { used; need further } \\
\text { validation and } \\
\text { standardization of } \\
\text { the technique }\end{array}$ & $\begin{array}{l}\text { Good reproducibility } \\
\text { even there are } \\
\text { contrasting results } \\
\text { con intra and inter } \\
\text { observer variation } \\
{[69,85]}\end{array}$ & $\begin{array}{l}\text { An increased W/L } \\
\text { ratio of retinal } \\
\text { arterioles was } \\
\text { found in patients } \\
\text { with hypertension } \\
\text { and history of } \\
\text { cerebrovascular } \\
\text { event [67-68] }\end{array}$ & $\begin{array}{l}\text { W/L ratio of retinal } \\
\text { arterioles correlates } \\
\text { with } \mathrm{M} / \mathrm{L} \text { ratio of } \\
\text { subcutaneous small } \\
\text { resistance arteries } \\
\text { (micromyography) } \\
{[75,85]}\end{array}$ \\
\hline $\mathrm{AO}$ & $\begin{array}{l}\text { Non-invasive; } \\
\text { relatively easy }\end{array}$ & $\begin{array}{l}\text { Not extensively } \\
\text { used; need further } \\
\text { validation }\end{array}$ & Good reproducibility & $\begin{array}{l}\text { Blood pressure } \\
\text { values and age } \\
\text { associated with } \\
\text { W/L ratio of retinal } \\
\text { arterioles [77]. }\end{array}$ & $\begin{array}{l}\text { Strong linear correlation } \\
\text { between } W / L \text { ratio } \\
\text { of retinal arterioles } \\
\text { and } M / L \text { ratio of } \\
\text { subcutaneous small } \\
\text { resistance arteries } \\
\text { (micromyography) [85] }\end{array}$ \\
\hline
\end{tabular}

AVR: arteriolar to venular ratio; SLDF: scanner laser Doppler flowmetry; AO: adaptive optics; $\mathrm{M} / / \mathrm{L}$ ratio: media to lumen ratio; W/L ratio: wall to lumen ratio; 
flow. The ratio between mean blood pressure, evaluated either with invasive or non-invasive methods, and maximum arterial post-ischemic flow represents the forearm minimum vascular resistance.

\section{Micromyography}

The gold standard technique for the evaluation of structural alterations of small resistance arteries in humans is wire or pressure micromyography [24-26]. Wire micromyography was developed by Mulvany and Halpern in the 1970s [27-28]. This technique was used for the evaluation of the morphology and function of small arteries obtained from biopsies of subcutaneous tissue from the gluteal or the anterior abdominal regions (taken during elective surgery), in normotensive individuals as well as in hypertensive patients [22, 24, 29].

Small resistance artery segments, few millimeters long, were dissected free of periadventitial fat tissue, and then cannulated with $40 \mu \mathrm{m}$ diameter steel wires, resulting in a ring preparation mounted on a wire micromyography. Mechanical stretch may be applied through a micrometric screw, while a force transducer records the passive tension that developed. The vessel may also be maintained on a constant stretch and stimulated to contract by adding various substances to the organ bath, such as norepinephrine, potassium, serotonin, thus allowing the measurements of the active tension developed. It is important that the vessel is not damaged during the mounting procedure, because even a minimal damage may lead to alterations in the contractile responses and errors during the measurement of morphological parameters.

Subsequently, the vessel, in relaxed condition, is transferred on the stage of an immersion lens microscope, and through a micrometric ocular (magnitude about 600x), the total wall thickness, the adventitia, media and intima thicknesses as well as the internal diameter are measured. The most useful parameter obtained with micromyographic approaches is represented by $M / L$ ratio, since it is independent from the vessel's dimensions [30-31].

Similar to the wire micromyography is the perfusion-pressure micromyography: isolated vessels are mounted in a pressurized myograph chamber and slipped into two glass microcannulae, connected to a perfusion system that allows a constant intraluminal pressure of $60 \mathrm{mmHg}$ [31]. Morphology of the vessels is evaluated by computer-assisted video analyzers. Recently, reference values for $\mathrm{M} / \mathrm{L}$ ratio in subcutaneous small arteries have been published, according to age and sex [32].

No difference between the two techniques was observed, providing that the vessels were analyzed under similar conditions [24, 30,33]. Pressure micromyogra- phy allows a better evaluation of functional responses, although the precision of the morphological assessment can be slightly lower [30]. The evaluation of vascular myogenic tone and mechanical properties need a stepwise increase in intraluminal pressure, their estimation therefore a pressure micromyographic approach [34-36].

Finally, pressure perfusion system allows to transfer small interfering RNA in vessels and plasmid or adenoviral vectors, which mediate gene delivery for evaluate vascular phenotype following gene modulation [37-38]. Micromyographic approaches were extensively used in the last decades, but the technique is limited by the local invasiveness of the procedure, requiring tissue biopsies.

\section{Videomicroscopy/capillaroscopy}

Capillaroscopy is a reliable tool for the evaluation of capillary density in the cutaneous/subcutaneous vascular bed. This non-invasive method permits to study morphological and functional characteristics of the distal microcirculation. Currently the optical probe capillaroscopy is used; a polarized light at variable magnifications allows direct visualization of the capillaries on a monitor. The examination is performed with the patient in a sitting position, with the palm of the non-dominant hand resting on the observation plane. The nailfold area or the dorsum of the IV finger is analyzed by applying a drop of diaphanous oil (usually cedar oil or paraffin) to minimize light reflections and improve resolution without interfering with the optical properties [39].

After a basal evaluation the microcirculation is studied under conditions of maximum perfusion (obtained with venous congestion through the inflation of a sphygmomanometer applied to the base of the finger up to $60 \mathrm{mmHg}$ for 2 minutes) to recruit those vessels not perfused in basal conditions and, therefore, to evaluate the total density of vessels of capillary district. The same procedure is used also to evaluate capillary density in the forearm skin. Capillary morphology and capillary density may be evaluated by in traditional capillaroscopy, while dynamic capillaroscopy explores also capillary flow velocity [40]. In combination with intravenous administration of fluorescent dyes, such as sodium fluoresceine or indocyanide green (fluorescence videomicroscopy or fluorescence angiography), capillaroscopy can be used to evaluate the heterogeneity of capillary flow distribution, or to disclose structures that cannot be seen with traditional capillaroscopy (such as capillary aneurisms) and to follow the transcapillary diffusion of markers (capillary permeability) [41]. Capillary density, defined as the number of capillaries for unit of skin area is clearly reduced in essential hypertension [40]. This 
technique is influenced by skin transparency, manicure procedures, and it is partly operator-dependent.

\section{Retinal district}

Retinal microcirculation represents a microvascular district that can be directly and easily observed with relatively simple approaches, such as a slit lamp or an ophthalmoscope [42]. Vasculature of the eye shares anatomic, physiological and embryological features with the heart and the brain [42-43], thus it can be assumed that also pathological changes occurring in these districts are similar [44].

Several studies have analyzed the relationship between retinal arteriolar signs and their associations with systemic vascular disease [45]. Evidences about the association between retinal microvasculature signs (i.e.: microaneurysms, cotton wool spots, etc.) and cardiovascular outcomes have been previously reported [46]. Wong et al investigated the association between markers of microvasculature damage in retinal district and the incidence of coronary artery disease [47]: the authors have used the ratio between arteriolar and venular external diameters (AVR) to assess retinal arteriolar narrowing, demonstrating the presence of lower values in hypertensive patients compared to normotensive controls [47]. Results were confirmed by a meta-analysis performed by Ding et al [48]: retinal arteriolar narrowing and venular widening was independently associated with an increased risk of hypertension [47].

However, the prognostic role of AVR is not well established, as a correlation between AVR and incidence of cardiovascular events was detected only in women [13]. Also, its potential role in stratifying hypertensive patients according to organ damage has been questioned: there is no relationship between quartiles of AVR and left ventricular mass, carotid artery intima-media thickness or urinary albumin excretion [49]. A meta-analysis of relationship between retinal vessel caliber (AVR, central retina artery equivalent, central retina vein equivalent) and future stroke events revealed that wider retinal venular caliber predicted stroke, whereas the caliber of retinal arterioles was not associated with stroke [1].

Other authors have also proposed a topological assessment of retinal microvasculature. Hughes et al. [50] have demonstrated the possibility to quantify topological changes in retinal vascular architecture through a specific software: they found an association between the presence of essential hypertension and an increased arteriolar length-to-diameter ratio. In hypertensive patients compared with normotensive controls also changes in arteriolar topology, indicative of rarefaction were observed, including a reduction in the number of terminal branches [50]. These differences were even more pronounced in patients with malignant hyperten- sion. Moreover, antihypertensive drugs seem to beneficially affect some of the above-mentioned parameters [51].

Recent improvements in optical imaging techniques enabled the generation of high-resolution, non-invasive capillary perfusion maps with a retinal function images with consequent investigation of segmentation results and fractal analysis [52]. In particular, calculation of fractal dimensions of retinal microvasculature has been investigated as an index of complexity of the retinal network and, for this index, prognostic relevance was demonstrated. In a cohort of more than 3000 individuals, those with suboptimal retinal vascular fractal dimensions (lowest and highest quartiles) had 40-50\% higher 14-year mortality for coronary heart disease than those with optimal fractal dimensions, independently from main baseline features as age and other risk factors [53].

Is should be however mentioned that in the majority of the studies performed in the last decades, the assessment of retinal vascular alterations was performed with funduscameras or slit-lamps and retinal photographs obtained were interpreted by ophthalmologists and quantified according the Keith-Wegener-Barker grading system; however some concerns have been raised in relation to this largely used approach [54-55].

In fact, criticism with respect to the reproducibility of grade I and grade II retinopathy has been raised, since even experienced investigators showed an high inter-observer and intra-observer variability [56-57]. For these reasons according to 2013 European Society of Hypertension/European Society of Cardiology Guidelines fundus oculi examination should be considered only in difficult- to-control or resistant hypertensive patients and is not recommended in mild-to-moderate hypertensive patients without diabetes [1].

Potential assessment of endothelial function has been proposed for retinal microvascular network: flicker light-induced retinal vasodilation evaluated by dynamic vessel analysis has been hypothesized to be an indicator of endothelial dysfunction [58]. Even if a potential clinical relevance has been shown in previous reports [59], further validating studies are needed [58].

\section{Optical coherence tomography (OCT)}

Intensity graph-assisted measurements using spectral- domain optical coherence tomography (OCT) may provide objective measurements of retinal vessels lumen diameters and wall thicknesses [60]. In a previous report, OCT has been proposed for the investigation of retinal vessels: Schuster et colleagues [61] have demonstrated a relationship between mean arterial blood pressure and OCT-based AVR. Moreover Muraoka et al. [62] have evaluated outer and inner diameters in four 
large retinal arteries and veins in 238 subjects without ocular disease, identifying a circular region around the optic disc, then performing an OCT scanning. Arterial and venous diameters were similar to those obtained with other techniques, such as scanned laser Doppler flowmetry (SLDF), even if a direct comparison between two methods was not performed. Additionally, the authors found that wall thicknesses of arteries and veins were significantly thickened as a consequence of aging and hypertension. However no adjustment for patients' risk profile (i.e. diabetes or dyslipidemia) was performed. Recent improvements in OCT technology have allowed the potential exploration of the choroid. Variations in the choroidal thickness have been associated to systolic blood pressure values in healthy subjects [63]. Choroidal thickness, measured with spectral-domain OCT, was decreased in patients with arterial hypertension. This was attributed to arteriolar sclerosis and vascular contraction, caused by a high intravascular pressure in the choroid [64]. On the contrary, Gök et al. [65] have reported that arterial hypertension do not influence subfoveal choroidal thickness in comparison to healthy controls. OCT may be instrumental in order to document hypertensive retinopathy and choroidopathy severity, however further studies are needed to better understand the impact of OCT assessments on patients' cardiovascular risk profile and on outcomes [66].

\section{Scanning laser Doppler flowmetry (SLDF)}

About ten years ago, Harazny, Michelson, and Schmieder proposed an interesting and new noninva- sive approach for the assessment of structural abnormalities in the retinal vascular district. A quantification of the wall-to-lumen ratio (W/L ratio) of retinal arterioles was obtained using scanning laser doppler flowmetry (SLDF) (Heidelberg Retina Flowmeter, Heidelberg Engineering, Heidelberg, Germany) and appropriate software analysis [67-68].

This technique performs a confocal measurement of the external diameter of retinal arteriole and an estimation of the internal diameter with a laser Doppler approach. Arterioles with dimensions between 80 and $140 \mu \mathrm{m}$ in the superficial retinal layer may be investigated. Measurements of morphological parameters are performed offline with an automatic full-field perfusion imaging analysis: the outer arteriole diameter is measured in reflection images, and the lumen diameter is measured in perfusion images. The software automatically compares the two images taken in the same retinal area (Figure 1). Advantages of this approach are related to the easy repeatability with very little discomfort for the patients, and, according to the Authors to a relatively low inter- and intraobserver coefficient of variation of the measure (less than 10\%) [69]. However, the reproducibility of the non-invasive measurement of the $\mathrm{W} / \mathrm{L}$ ratio with the concerned technical approach in real life situations is probably less satisfactory, due to the possible problems in a correct estimation of the internal diameter with the Doppler approach. In addition, the Heidelberg Retina Flowmeter in no more present in the market, thus limiting the scientific interest and possible clinical development of this approach.
A)

Reflection image

Flowimage

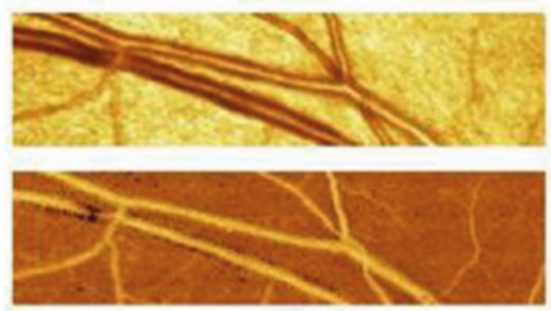

C)

\section{Reflection image}

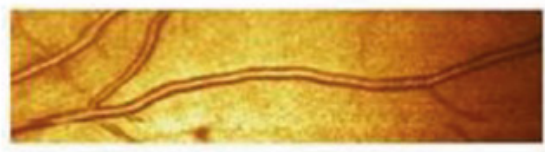

Flow image
B)

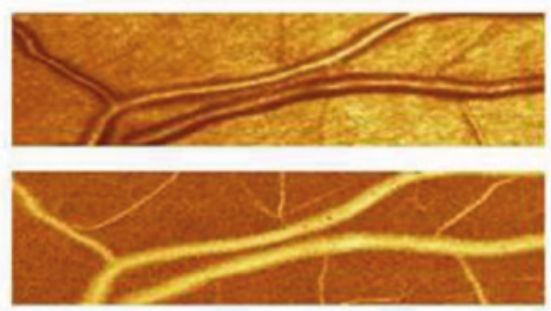

D)
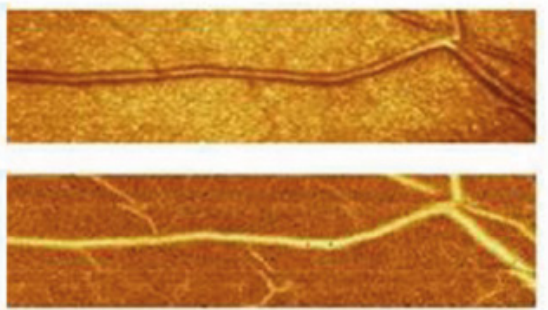

Figure 1. Reflection image and flow image in the retinal vascular bed assessed by Scanner laser Doppler flowmetry in four different regions of the eye $(A, B, C, D)$ 
There are however several evidences supporting the clinical relevance of the evaluation of the $\mathrm{W} / \mathrm{L}$ ratio of retinal arterioles. As previously mentioned, in hypertension an increase in the $\mathrm{M} / \mathrm{L}$ ratio of small resistance arteries seems to be present in different districts [9, 70]. Microvascular morphological changes observed peripheral district (e.g. subcutaneous tissue) might reflect similar changes in coronary or cerebral circulation [70]. An increased W/L ratio of retinal arterioles has been reported in patients with hypertension [68], with the history of a cerebrovascular event [67] or with other clinical signs of target organ damage, such as albuminuria, expression of the microvascular damage at the kidney level [71]. W/L ratio of retinal arterioles was also demonstrated to be correlated with peripheral, central, and 24-hour blood pressures [72-73].

When $W / L$ ratio and AVR of retinal vessels were compared, inconsistencies were detected: $W / L$ ratio of retinal arterioles was progressively higher in normotensive individuals, treated hypertensive individuals and hypertensive patients with a history of a cerebrovascular event, but this was not the case of AVR values; in addition, $W / L$ ratio but not $A V R$ values paralleled those observed for carotid intima-media thickness [74]. The $\mathrm{W} / \mathrm{L}$ ratio of retinal arterioles assessed with SLDF was compared with the $\mathrm{M} / \mathrm{L}$ ratio of subcutaneous small resistance arteries evaluated by wire micromyography. A rather good agreement between the two techniques, with a Pearson's correlation index above 0.76 was shown [75].

\section{Adaptive optics (AO)}

Recently, a novel and extremely promising approach became commercially available: direct measurement of $W / L$ ratio of retinal arterioles using an adaptive optics $(A O)$ imaging system ( $A O$ camera, Rtx-1, Imagine
Eyes, Orsay, France) [76-77]. The implementation of AO in a fuduscamera lead to a quite higher quality of images through the correction of wavefront aberrations: in fact such a technique has been widely employed in ground-based telescopes [78] to measure and correct atmospheric aberrations, allowing the formation of high-quality images of astronomical objects [76-77, 79-80]. In the retinal microvasculature this methods permits to investigate vessels from $20 \mu \mathrm{m}$ to more than $150 \mu \mathrm{m}$ of diameter [79-80]. A beam of light enters the eye, and a small amount is reflected back out of the eye and into the optical system: wavefront aberrations in the reflected image are sensed by a suitable image sensor in the system, and corrected for by a deformable mirror $[76,81]$. The achieved image resolution is of the order of $1 \mu \mathrm{m}$. The fundus illumination is obtained by a temporally low-coherent light-emitting diode flashed flood source at $840 \mathrm{~nm}$; the frequency of images acquiring is of $10 \mathrm{~Hz}$ for a total of 4 seconds. The final image provided by the instrument is the average of a sequence of such images [76] (Figure 2). In most cases pupil dilation is not needed, anyhow topical tropicamide can be applied to improve images acquiring.

The system, thus, provides images of a quality and resolution never previously obtained [81-82]. The vessel walls are clearly visible in most circumstances, provided that the eye fixation is correct and that the ocular media are clear. Studies in populations of normotensive subjects and hypertensive patients highlighted the potential role of $A O$ in assessing age- related remodeling of the retinal arterioles; in fact $\mathrm{W} / \mathrm{L}$ ratio of retinal arterioles has shown a linearly relationship with age in previous reports [77, 83-84]. Interestingly, it has been found a dependence of the $\mathrm{W} / \mathrm{L}$ ratio on the wall thickness, but not on the internal vessel's diameter.

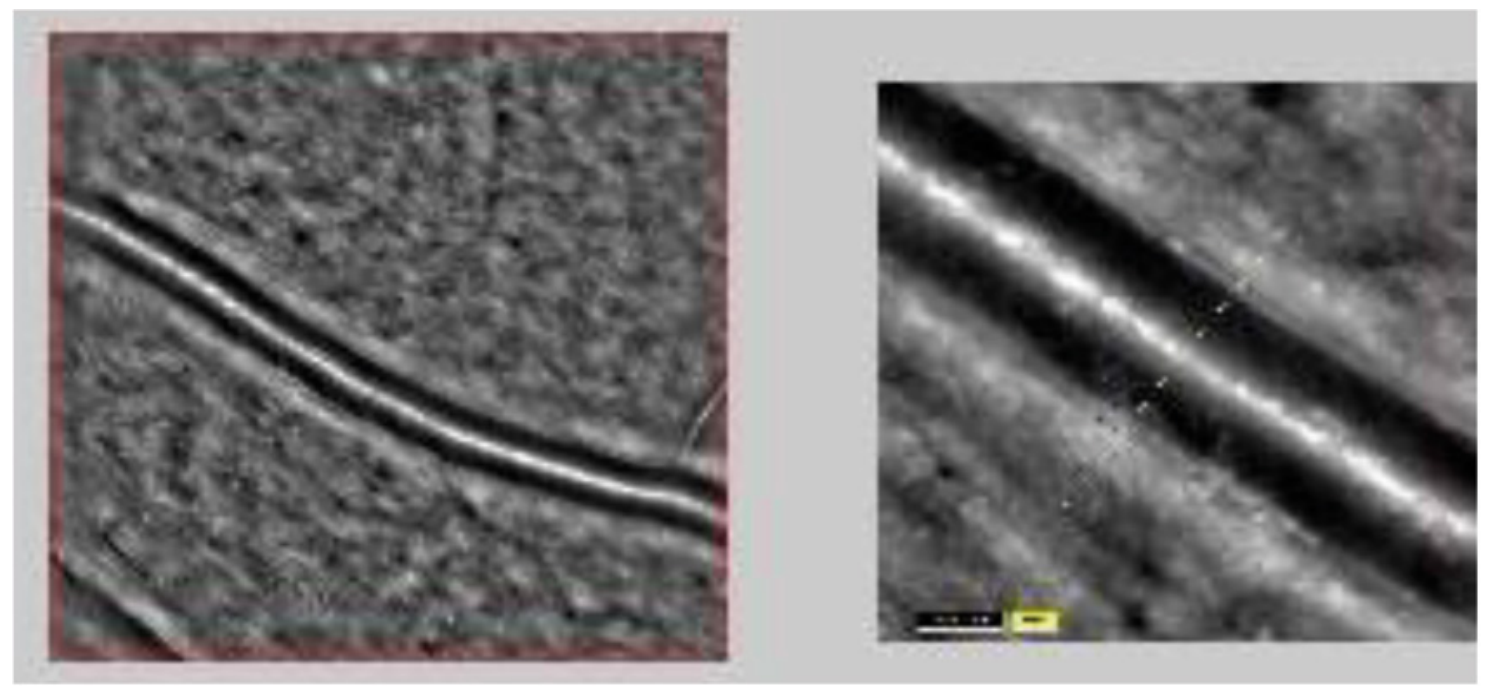

Figure 2. Retinal arteriolar vessel assessed by adaptive optics (AO) 
Rosenbaum et al have observed a correlation between age-corrected $\mathrm{W} / \mathrm{L}$ ratio of retinal arterioles and blood pressure values [77]. Blood pressure and age both independently increase $\mathrm{W} / \mathrm{L}$ ratio by thickening the arteriolar wall. Dealing with anti-hypertensive treatment, they have observed that even a short-term reduction in blood pressure obtained by antihypertensive drugs induced a decrease in $\mathrm{W} / \mathrm{L}$ ratio of retinal arterioles due to an increase in the diameter rather than to wall thickness changes; by contrast, no modifications were observed in subjects with negligible reduction in blood pressure values during treatment. In treated and controlled hypertensives under monotherapy $\mathrm{W} / \mathrm{L}$ ratio normalization was observed, to be ascribed to combined wall thickness decrease and lumen dilatation independently of antihypertensive pharmacological classes, suggesting that adequate control of blood pressure may provide protection form microvascular alterations.

Recently, De Ciuceis $C$ et al. have compared M/L ratio of subcutaneous small resistance arteries assessed by wire micromyography and $\mathrm{W} / \mathrm{L}$ ratio of retinal arterioles assessed by $A O$ and SLDF in a population of hypertensive and/or obese patients [85]. The correlation between the $\mathrm{M} / \mathrm{L}$ ratio of subcutaneous small arteries and the $\mathrm{W} / \mathrm{L}$ ratio of retinal arterioles evaluated by $\mathrm{AO}$ $\left(r=0.84, r^{2}=0.64, p<0.001\right)$ was closer that that observed between the $M / L$ ratio of subcutaneous small arteries and the $W / L$ ratio of retinal arterioles assessed by SLDF $\left(r=0.48, r^{2}=0.2649, p<0.05\right.$, slopes of the relations: $p<0.01$ AO vs. SLDF). Receiver operating characteristic curves of $A O$ and SLDF exploring the ability of $\mathrm{W} / \mathrm{L}$ ratio to discriminate patients with a $\mathrm{M} / \mathrm{L}$ ratio above or below the cutpoint of 0.05 resulted significantly different in term of sensitivity and specificity, clearly in favor of adaptive optics $(p<0.05)$. When intraobserver and interobserver coefficient of variation have been analyzed, smaller values were observed for AO compared to SLDF, confirming the very good reproducibility of $A O$ [86].

\section{Conclusions}

There is convincing evidence of a strong relationship between alterations in the microcirculation and cardiovascular outcomes. Detection of such alterations may be clinically useful for a better stratification of cardiovascular risk and possibly for guiding antihypertensive treatment, through a precise assessment of possible regression of microvascular damage. New technologies made it simpler to assess the microvascular structural changes and non-invasive techniques, especially in the retinal vascular bed, may allow us to perform such evaluations in almost all hypertensive patients. However, at present we have no direct evidence of a prognostic value of non-invasive measures of microvascular structure.

Adaptive optics is a promising approach for non-invasive evaluation of microvascular structure. Nevertheless, future studies are needed in order to establish a possible prognostic relevance of this method and its usefulness for monitoring the effectiveness of treatment.

\section{References}

1. Mancia G, Fagard R, Narkiewicz K, Redon J, Zanchetti A, Böhm M, et al. 2013 ESH/ESC guidelines for the management of arterial hypertension: the Task Force for the Management of Arterial Hypertension of the European Society of Hypertension (ESH) and of the European Society of Cardiology (ESC). Eur Heart J. 2013;34(28): 2159-219.

2. De Ciuceis C, Rizzoni D, Agabiti Rosei C, Porteri E, Boari G, Agabiti Rosei E. Remodelling of Small Resistance Arteries in Essential Hypertension. High Blood Press Cardiovasc Prev. 2006;13(1):1-6.

3. Schiffrin EL. Remodeling of resistance arteries in essential hypertension and effects of antihypertensive treatment. Am J Hypertens. 2004;17(12 Pt 1):1192-200.

4. Folkow B. Physiological aspects of primary hypertension. Physiol Rev. 1982;62(2):347-504

5. Christensen KL, Mulvany MJ. Location of Resistance Arteries. J Vasc Res. 2001;38(1):1-12.

6. Mulvany MJ, Aalkjaer C. Structure and function of small arteries. Physiol Rev. 1990;70(4):921-61.

7. Davis MJ, Ferrer PN, Gore RW. Vascular anatomy and hydrostatic pressure profile in the hamster cheek pouch. Am J Physiol. 1986;250(2 Pt 2):H291-303.

8. Heagerty AM, Aalkjaer C, Bund SJ, Korsgaard N, Mulvany MJ. Small artery structure in hypertension. Dual processes of remodeling and growth. Hypertens (Dallas, Tex 1979). 1993;21(4):391-7.

9. Rizzoni D, Palombo C, Porteri E, Muiesan ML, Kozàkovà M, La Canna G, et al. Relationships between coronary flow vasodilator capacity and small artery remodelling in hypertensive patients. J Hypertens. 2003;21(3): 625-31.

10. Grassi G, Seravalle G, Brambilla G, Facchetti R, Bolla G, Mozzi E, et al. Impact of the metabolic syndrome on subcutaneous microcirculation in obese patients. J Hypertens. 2010;28(8):1708-14.

11. Grassi G, Seravalle G, Scopelliti F, Dell'Oro R, Fattori L, Quarti-Trevano F, et al. Structural and functional alterations of subcutaneous small resistance arteries in severe human obesity. Obesity (Silver Spring). 2010;18(1):92-8.

12. Rizzoni D, Porteri E, Guelfi D, Muiesan ML, Valentini U, Cimino A, et al. Structural alterations in subcutaneous small arteries of normotensive and hypertensive patients with non-insulin-dependent diabetes mellitus. Circulation. 2001;103(9):1238-44. 
13. Rizzoni D, Porteri E, Boari GEM, De Ciuceis C, Sleiman I, Muiesan ML, et al. Prognostic significance of small-artery structure in hypertension. Circulation. 2003;108(18):2230-5.

14. Buus NH, Mathiassen ON, Fenger-Grøn M, Præstholm MN, Sihm I, Thybo NK, et al. Small artery structure during antihypertensive therapy is an independent predictor of cardiovascular events in essential hypertension. J Hypertens. 2013;31(4):791-7.

15. Mulvany MJ. Structural Abnormalities of the Resistance Vasculature in Hypertension. J Vasc Res. 2003;40(6): 558-60.

16. Mulvany MJ. Small artery remodeling and significance in the development of hypertension. News Physiol Sci. 2002;17:105-9.

17. Bohlen HG. Localization of vascular resistance changes during hypertension. Hypertension. 1986;8(3):181-3.

18. Schiffrin EL. Reactivity of small blood vessels in hypertension: relation with structural changes. State of the art lecture. Hypertens (Dallas, Tex 1979). 1992;19(2 Suppl):II1-9.

19. Antonios TF, Singer DR, Markandu ND, Mortimer PS, MacGregor GA. Structural skin capillary rarefaction in essential hypertension. Hypertens (Dallas, Tex 1979). 1999;33(4):998-1001.

20. Antonios TF, Singer DR, Markandu ND, Mortimer PS, MacGregor GA. Rarefaction of skin capillaries in borderline essential hypertension suggests an early structural abnormality. Hypertens (Dallas, Tex 1979). 1999;34(4 Pt 1):655-8.

21. Paiardi S, Rodella LF, De Ciuceis C, Porteri E, Boari GEM, Rezzani R, et al. Immunohistochemical evaluation of microvascular rarefaction in hypertensive humans and in spontaneously hypertensive rats. Clin Hemorheol Microcirc. 2009;42(4):259-68.

22. Rosei EA, Rizzoni D, Castellano M, Porteri E, Zulli R, Muiesan ML, et al. Media: lumen ratio in human small resistance arteries is related to forearm minimal vascular resistance. J Hypertens. 1995;13(3):341-7.

23. Pedrinelli R, Spessot M, Salvetti A. Reactive hyperemia during short-term blood flow and pressure changes in the hypertensive forearm. J Hypertens. 1990;8(5):467-71.

24. Schiffrin EL, Hayoz D. How to assess vascular remodelling in small and medium-sized muscular arteries in humans. J Hypertens. 1997;15(6):571-84

25. Rizzoni D, Aalkjaer C, De Ciuceis C, Porteri E, Rossini C, Rosei CA, et al. How to assess microvascular structure in humans. High Blood Press Cardiovasc Prev. 2011;18(4):169-77.

26. Rizzoni D, Agabiti-Rosei E. Structural abnormalities of small resistance arteries in essential hypertension. Intern Emerg Med. 2012;7(3): 205-12.

27. Mulvany MJ, Hansen OK, Aalkjaer C. Direct evidence that the greater contractility of resistance vessels in spontaneously hypertensive rats is associated with a narrowed lumen, a thickened media, and an increased number of smooth muscle cell layers. Circ Res. 1978;43(6):854-64.

28. Mulvany MJ, Halpern W. Contractile properties of small arterial resistance vessels in spontaneously hypertensive and normotensive rats. Circ Res. 1977;41(1):19-26.

29. Aalkjaer C, Eiskjaer H, Mulvany MJ, Jespersen B, Kjaer T, Sørensen SS, et al. Abnormal structure and function of isolated subcutaneous resistance vessels from essential hypertensive patients despite antihypertensive treatment. J Hypertens. 1989;7(4):305-10.

30. Schiffrin EL, Deng LY. Structure and function of resistance arteries of hypertensive patients treated with a beta-blocker or a calcium channel antagonist. J Hypertens. 1996;14(10):1247-55.

31. Endemann DH, Pu Q, De Ciuceis C, Savoia C, Virdis A, Neves MF, et al. Persistent remodeling of resistance arteries in type 2 diabetic patients on antihypertensive treatment. Hypertens (Dallas, Tex 1979). 2004;43(2): 399-404.

32. Bruno RM, Grassi G, Seravalle G, Savoia C, Rizzoni D, Virdis A. Age- and Sex-Specific Reference Values for Media/Lumen Ratio in Small Arteries and Relationship With Risk FactorsNovelty and Significance. Hypertension. 2018;71(6):1193-200.

33. Falloon BJ, Stephens N, Tulip JR, Heagerty AM. Comparison of small artery sensitivity and morphology in pressurized and wire-mounted preparations. Am J Physiol. 1995;268(2 Pt 2):H670-8.

34. Carnevale D, Vecchione C, Mascio G, Esposito G, Cifelli G, Martinello K, et al. PI3Kү inhibition reduces blood pressure by a vasorelaxant Akt/Ltype calcium channel mechanism. Cardiovasc Res. 2012;93(1):200-9.

35. Litteri G, Carnevale D, D’Urso A, Cifelli G, Braghetta P, Damato A, et al. Vascular smooth muscle Emilin-1 is a regulator of arteriolar myogenic response and blood pressure. Arterioscler Thromb Vasc Biol. 2012;32(9):2178-84.

36. Zacchigna L, Vecchione C, Notte A, Cordenonsi M, Dupont S, Maretto S, et al. Emilin1 links TGF-beta maturation to blood pressure homeostasis. Cell. 2006;124(5):929-42.

37. Vecchione C, Carnevale D, Di Pardo A, Gentile MT, Damato A, Cocozza G, et al. Pressure-induced vascular oxidative stress is mediated through activation of integrin-linked kinase 1/betaPIX/Rac-1 pathway. Hypertens (Dallas, Tex 1979). 2009;54(5):1028-34.

38. Vecchione C, Frati A, Di Pardo A, Cifelli G, Carnevale D, Gentile MT, et al. Tumor necrosis factor-alpha mediates hemolysis-induced vasoconstriction and the cerebral vasospasm evoked by subarachnoid hemorrhage. Hypertens (Dallas, Tex 1979). 2009;54(1):150-6.

39. Cutolo M, Sulli A, Pizzorni C, Accardo S. Nailfold videocapillaroscopy assessment of microvascular damage in systemic sclerosis. J Rheumatol. 2000;27(1):155-60.

40. Virdis A, Savoia C, Grassi G, Lembo G, Vecchione C, Seravalle G, et al. Evaluation of microvascular structure in humans. J Hypertens. 2014;32(11):2120-9.

41. Shore AC. Capillaroscopy and the measurement of capillary pressure. Br J Clin Pharmacol. 2000;50(6):501-13.

42. Flammer J, Konieczka K, Bruno RM, Virdis A, Flammer AJ, Taddei S. The eye and the heart. Eur Heart J. 2013;34(17):1270-8.

43. Wong TY, Mitchell P. Hypertensive retinopathy. N Engl J Med. 2004;351(22):2310-7.

44. Agabiti-Rosei E, Rizzoni D. Microvascular structure as a prognostically relevant endpoint. J Hypertens. 2017;35(5):914-21.

45. Lehmann M V., Schmieder RE. Remodeling of Retinal Small Arteries in Hypertension. Am J Hypertens. 2011;24(12):1267-73.

46. Wong TY, McIntosh R. Systemic associations of retinal microvascular signs: a review of recent population-based studies. Ophthalmic Physiol Opt. 2005;25(3):195-204. 
47. Wong TY, Klein R, Sharrett AR, Duncan BB, Couper DJ, Tielsch JM, et al. Retinal arteriolar narrowing and risk of coronary heart disease in men and women. The Atherosclerosis Risk in Communities Study. JAMA. 2002 Mar;287(9):1153-9.

48. Ding J, Wai KL, McGeechan K, Ikram MK, Kawasaki R, Xie J, et al. Retinal vascular caliber and the development of hypertension: a meta-analysis of individual participant data. J Hypertens. 2014;32(2):207-15.

49. Masaidi M, Cuspidi C, Giudici V, Negri F, Sala C, Zanchetti A, et al. Is retinal arteriolar-venular ratio associated with cardiac and extracardiac organ damage in essential hypertension? J Hypertens. 2009;27(6):1277-83.

50. Hughes AD, Martinez-Perez E, Jabbar A-S, Hassan A, Witt NW, Mistry PD, et al. Quantification of topological changes in retinal vascular architecture in essential and malignant hypertension. J Hypertens. 2006;24(5): 889-94.

51. Hughes AD, Stanton A V, Jabbar AS, Chapman N, Martinez-Perez ME, McG Thom SA. Effect of antihypertensive treatment on retinal microvascular changes in hypertension. J Hypertens. 2008;26(8):1703-7.

52. Jiang H, Debuc DC, Rundek T, Lam BL, Wright CB, Shen M, et al. Automated segmentation and fractal analysis of high-resolution non-invasive capillary perfusion maps of the human retina. Microvasc Res. 2013;89:172-5.

53. Liew G, Mitchell P, Rochtchina E, Wong TY, Hsu W, Lee ML, et al. Fractal analysis of retinal microvasculature and coronary heart disease mortality. Eur Heart J. 2011;32(4):422-9.

54. Mollentze WF, Stulting AA, Steyn AF. Ophthalmoscopy versus non-mydriatic fundus photography in the detection of diabetic retinopathy in black patients. South African Med J. 1990;78(5):248-50.

55. Cheung CY, Ikram MK, Sabanayagam C, Wong TY. Retinal microvasculature as a model to study the manifestations of hypertension. Hypertens (Dallas, Tex 1979). 2012;60(5):1094-103.

56. Dimmitt SB, West JN, Eames SM, Gibson JM, Gosling P, Littler WA. Usefulness of ophthalmoscopy in mild to moderate hypertension. Lancet (London, England). 1989;1(8647):1103-6.

57. van den Born B-JH, Hulsman CAA, Hoekstra JBL, Schlingemann RO, van Montfrans GA. Value of routine funduscopy in patients with hypertension: systematic review. BMJ. 2005;331(7508):73.

58. Lim M, Sasongko MB, Ikram MK, Lamoureux E, Wang JJ, Wong TY, et al. Systemic Associations of Dynamic Retinal Vessel Analysis: A Review of Current Literature. Microcirculation. 2013;20(3):257-68.

59. Nagel E, Vilser W, Lanzl I. Age, blood pressure, and vessel diameter as factors influencing the arterial retinal flicker response. Invest Ophthalmol Vis Sci. 2004;45(5):1486-92.

60. Rim TH, Choi YS, Kim SS, Kang M-J, Oh J, Park S, et al. Retinal vessel structure measurement using spectral-domain optical coherence tomography. Eye (Lond). 2016;30(1):111-9.

61. Schuster AK-G, Fischer JE, Vossmerbaeumer C, Vossmerbaeumer U. Optical coherence tomography-based retinal vessel analysis for the evaluation of hypertensive vasculopathy. Acta Ophthalmol. 2015;93(2):e148-53.

62. Muraoka Y, Tsujikawa A, Kumagai K, Akiba M, Ogino K, Murakami T, et al. Age- and hypertension-dependent changes in retinal vessel diameter and wall thickness: an optical coherence tomography study. Am J Ophthalmol. 2013;156(4):706-14.

63. Usui S, Ikuno Y, Akiba M, Maruko I, Sekiryu T, Nishida K, et al. Circadian changes in subfoveal choroidal thickness and the relationship with circulatory factors in healthy subjects. Invest Ophthalmol Vis Sci. 2012;53(4):2300-7.

64. Akay F, Gundogan FC, Yolcu U, Toyran S, Uzun S. Choroidal Thickness in Systemic Arterial Hypertension. Eur J Ophthalmol. 2016;26(2):152-7.

65. Gök M, Karabas VL, Emre E, Aksar AT, Aslan MS, Ural D. Evaluation of choroidal thickness via enhanced depth-imaging optical coherence tomography in patients with systemic hypertension. Indian J Ophthalmol. 2015;63(3):239-43.

66. Ahn SJ, Woo SJ, Park KH. Retinal and choroidal changes with severe hypertension and their association with visual outcome. Invest Ophthalmol Vis Sci. 2014;55(12):7775-85.

67. Harazny JM, Ritt M, Baleanu D, Ott C, Heckmann J, Schlaich MP, et al. Increased wall:Iumen ratio of retinal arterioles in male patients with a history of a cerebrovascular event. Hypertens (Dallas, Tex 1979). 2007;50(4):623-9.

68. Ritt M, Harazny JM, Ott C, Schlaich MP, Schneider MP, Michelson G, et al. Analysis of retinal arteriolar structure in never-treated patients with essential hypertension. J Hypertens. 2008;26(7):1427-34.

69. Harazny JM, Raff U, Welzenbach J, Ott C, Ritt M, Lehmann M, et al. New software analyses increase the reliability of measurements of retinal arterioles morphology by scanning laser Doppler flowmetry in humans. J Hypertens. 2011;29(4):777-82.

70. Rizzoni D, De Ciuceis C, Porteri E, Paiardi S, Boari GEM, Mortini P, et al. Altered structure of small cerebral arteries in patients with essential hypertension. J Hypertens. 2009;27(4):838-45.

71. Ritt M, Harazny JM, Ott C, Schneider MP, Schlaich MP, Michelson G, et al. Wall-to-lumen ratio of retinal arterioles is related with urinary albumin excretion and altered vascular reactivity to infusion of the nitric oxide synthase inhibitor $\mathrm{N}$-monomethyl-L-arginine. J Hypertens. 2009;27(11):2201-8

72. Salvetti M, Agabiti Rosei C, Paini A, Aggiusti C, Cancarini A, Duse S, et al. Relationship of wall-to-lumen ratio of retinal arterioles with clinic and 24-hour blood pressure. Hypertens (Dallas, Tex 1979). 2014;63(5):1110-5.

73. Ott C, Raff U, Harazny JM, Michelson G, Schmieder RE. Central pulse pressure is an independent determinant of vascular remodeling in the retinal circulation. Hypertens (Dallas, Tex 1979). 2013;61(6):1340-5.

74. Baleanu D, Ritt M, Harazny J, Heckmann J, Schmieder RE, Michelson G. Wall-to-lumen ratio of retinal arterioles and arteriole-to-venule ratio of retinal vessels in patients with cerebrovascular damage. Invest Ophthalmol Vis Sci. 2009;50(9):4351-9.

75. Rizzoni D, Porteri E, Duse S, De Ciuceis C, Rosei CA, La Boria E, et al. Relationship between media-to-lumen ratio of subcutaneous small arteries and wall-to-lumen ratio of retinal arterioles evaluated noninvasively by scanning laser Doppler flowmetry. J Hypertens. 2012;30(6): 1169-75.

76. Koch E, Rosenbaum D, Brolly A, Sahel J-A, Chaumet-Riffaud P, Girerd X, et al. Morphometric analysis of small arteries in the human retina using adaptive optics imaging: relationship with blood pressure and focal vascular changes. J Hypertens. 2014;32(4):890-8. 
77. Rosenbaum D, Mattina A, Koch E, Rossant F, Gallo A, Kachenoura N, et al. Effects of age, blood pressure and antihypertensive treatments on retinal arterioles remodeling assessed by adaptive optics. J Hypertens. 2016;34(6):1115-22.

78. Rodríguez C, Ji N. Adaptive optical microscopy for neurobiology. Curr Opin Neurobiol. 2018;50:83-91.

79. Chui TYP, Gast TJ, Burns SA. Imaging of vascular wall fine structure in the human retina using adaptive optics scanning laser ophthalmoscopy. Invest Ophthalmol Vis Sci. 2013;54(10):7115-24.

80. Hillard JG, Gast TJ, Chui TYP, Sapir D, Burns SA. Retinal Arterioles in Hypo-, Normo-, and Hypertensive Subjects Measured Using Adaptive Optics. TransI Vis Sci Technol. 2016;5(4):16.

81. Rizzoni D, Docchio F. Assessment of retinal arteriolar morphology by noninvasive methods: the philosopher's stone? J Hypertens. 2016;34(6):1044-6.

82. Carroll J, Kay DB, Scoles D, Dubra A, Lombardo M. Adaptive optics retinal imaging--clinical opportunities and challenges. Curr Eye Res. 2013;38(7):709-21.

83. Meixner E, Michelson G. Measurement of retinal wall-to-lumen ratio by adaptive optics retinal camera: a clinical research. Graefe's Arch Clin Exp Ophthalmol. 2015;253(11):1985-95.

84. Arichika S, Uji A, Ooto S, Muraoka Y, Yoshimura N. Effects of age and blood pressure on the retinal arterial wall, analyzed using adaptive optics scanning laser ophthalmoscopy. Sci Rep. 2015;5(1):12283.

85. De Ciuceis C, Agabiti Rosei C, Caletti S, Trapletti V, Coschignano MA, Tiberio GAM, et al. Comparison between invasive and noninvasive techniques of evaluation of microvascular structural alterations. J Hypertens. 2018;36(5):1154-63.

86. Rosenbaum D, Koch E, Girerd X, Rossant F, Pâques M. Imaging of retinal arteries with adaptative optics, feasibility and reproducibility. Ann Cardiol Angeiol (Paris). 2013;62(3):184-8.

87. Hern S, Mortimer PS. Visualization of dermal blood vessels--capillaroscopy. Clin Exp Dermatol. 1999;24(6):473-8.

88. Serne EH, Gans ROB, ter Maaten JC, Tangelder G-J, Donker AJM, Stehouwer CDA. Impaired Skin Capillary Recruitment in Essential Hypertension Is Caused by Both Functional and Structural Capillary Rarefaction. Hypertension. 2001;38(2):238-42.

89. Vázquez SG, Barreira N, Penedo MG, Rodríguez-Blanco M. Reliable monitoring system for arteriovenous ratio computation. Comput Med Imaging Graph. 2013;37(5-6):337-45.

90. Masters BR. Fractal analysis of the vascular tree in the human retina. Annu Rev Biomed Eng. 2004;6:427-52.

91. Liew G, Wang JJ, Cheung N, Zhang YP, Hsu W, Lee ML, et al. The retinal vasculature as a fractal: methodology, reliability, and relationship to blood pressure. Ophthalmology. 2008;115(11):1951-6.

92. Cheung N, Liew G, Lindley RI, Liu EY, Wang JJ, Hand P, et al. Retinal fractals and acute lacunar stroke. Ann Neurol. 2010;68(1):107-11. 